\title{
Designation of Neotype Strains for Bacteroides amylophilus Hamlin and Hungate 1956 and Bacteroides succinogenes Hungate 1950
}

\author{
ELIZABETH P. CATO, ${ }^{1}$ W. E. C. MOORE, ${ }^{1}$ AND MARVIN P. BRYANT ${ }^{2}$ \\ Anaerobe Laboratory, College of Agriculture and Life Sciences, Virginia Polytechnic Institute and State \\ University, Blacksburg, Virginia 24061, ${ }^{1}$ and Departments of Dairy Science and Microbiology, University of \\ Illinois, Urbana, Illinois $61801^{2}$
}

Bacteroides amylophilus ATCC 29744 and B. succinogenes ATCC 19169 are described and here designated the neotype strains of these two species.

Bacteroides amylophilus and B. succinogenes have been shown to be important in metabolic activities in rumens: $B$. amylophilus in the digestion of starch and $B$. succinogenes in the degradation of cellulose $(2,13,15-17)$. Each of these organisms was well described when first isolated, but type strains were not formally designated, and the original isolates on which the descriptions were based have been lost.

In 1956, Hamlin and Hungate (13) described and named $B$. amylophilus, a new bacterial species that they had isolated from a bovine rumen. Although they sent cultures of the species to the American Type Culture Collection (ATCC), the strains were reported not to be viable when received by the ATCC. However, with the extensive description published by Hamlin and Hungate, strains later isolated by other investigators $(1,7,10,14)$ could be identified with confidence as members of this species.

In 1950, R. E. Hungate (16) described in great detail organisms that he had isolated earlier (15) from a bovine rumen, and he regarded them as belonging to a new species which he named $B$. succinogenes. Hungate did not designate a type strain for the species. However, since these bacteria were abundant in the rumen, fresh isolations were made, and many studies were made of their nutritional requirements and their activities (2-11). In 1953, a strain isolated by Bryant and Doetsch (5) from the rumen of a heifer was found to have the characteristics of B. succinogenes as reported by Hungate. This strain (S85) was deposited in the ATCC (ATCC 19169) as a representative strain of that species but was not formally designated as the neotype strain.

The purpose of this paper is to designate ATCC 29744 the neotype strain of B. amylophilus and ATCC 19169 the neotype strain of $B$. succinogenes, in accord with the rules of the Bacteriological Code (18).

\section{MATERIALS AND METHODS}

Bacterial strains. B. amylophilus ATCC 29744 $(\leftarrow$ VPI 2502B $\leftarrow$ Bryant [Hobson H18] $\leftarrow$ Hobson
H18) was isolated from a sheep rumen and described by Blackburn and Hobson (Rowett Research Institu'te, Aberdeen, Scotland) (1) in 1962. Characteristics reported for this strain were similar to those of $B$. amylophilus as listed by Hamlin and Hungate (13). B. succinogenes ATCC $19169(\leftarrow$ Bryant S85 $\rightarrow$ VPI 12249) was isolated from a bovine rumen by Bryant and Doetsch and described in 1954 (5).

Media and methods. The morphological characteristics and biochemical reactions of these strains were determined with media and by methods described previously (14) except where otherwise indicated. The basal broth medium used throughout (PY) contained (per $100 \mathrm{ml}$ ) $0.5 \mathrm{~g}$ of peptone, $0.5 \mathrm{~g}$ of Trypticase, $1.0 \mathrm{~g}$ of yeast extract, $0.5 \mathrm{mg}$ of crystalline equine hemin, $0.1 \mu \mathrm{l}$ of vitamin $\mathrm{K}_{1}$ (Sigma Chemical Co.), salts solution, resazurin, and cysteine as previously described (14). All media used to determine the reactions of $B$. succinogenes were supplemented with $30 \%$ (vol/vol) sterile prereduced rumen fluid and $0.4 \%$ $\mathrm{Na}_{2} \mathrm{CO}_{3}$ (PYRC basal medium). An atmosphere of $10 \%$ $\mathrm{CO}_{2}$ and $90 \%$ hydrogen was used for anaerobic incubation of plates.

\section{RESULTS AND DISCUSSION}

Bacteroides amylophilus Hamlin and Hungate 1956, 552 (later synonym: Ruminobacter amylophilus [Hamlin and Hungate] Prévot 1966,121 [19]).

The cells of $B$. amylophilus ATCC 29744, after incubation for 2 days in peptone-yeast extract-maltose broth, were pleomorphic, gramnegative, oval to long rods with tapered or round ends and included some swollen forms and irregularly curved cells, 0.9 to $1.2 \mu \mathrm{m}$ wide and 1.1 to $8.0 \mu \mathrm{m}$ long.

The organism was strictly anaerobic and nonmotile. It did not form spores or survive heating at $80^{\circ} \mathrm{C}$ for $10 \mathrm{~min}$. Only bicarbonate or $\mathrm{CO}_{2}$, a fermentable carbohydrate, and minerals were required for growth. $\mathrm{NH}_{3}$ was essential as a nitrogen source; amino acids were not used. Of the sugars tested, only starch, maltose, glycogen, or dextrin would support growth. Glucose was not utilized and rumen fluid was not stimulatory. Growth was equally good at 37 and $45^{\circ} \mathrm{C}$; there was no growth at 25 or $30^{\circ} \mathrm{C}$. 
Colonies in laked-blood roll-streak tubes after incubation for 4 days were pinpoint to $2 \mathrm{~mm}$ in diameter, circular, entire to slightly erose, convex to umbonate, translucent, colorless, shiny, and smooth. No internal structure was visible. Growth was very sparse on freshly prepared blood agar plates incubated anaerobically, and no colonies appeared on egg yolk agar plates.

Maltose broth cultures were turbid with a stringy sediment; the final $\mathrm{pH}$ after 5 days of incubation was 5.45. Products of the fermentation of maltose were (in milliequivalents per 100 $\mathrm{ml}$ of culture): succinic acid, 3.0; formic acid, 0.9; acetic acid, 0.7; and lactic acid, 0.3.

The reactions of this strain after 5 days of incubation and the reactions of this species as described by Hamlin and Hungate (13) are listed in Table 1. They reported that gelatin, when added in a $5 \%$ concentration to peptone-yeast extract-starch broth, was hydrolyzed by some strains. ATCC 29744 did not hydrolyze 5\% gelatin plus $0.1 \%$ glucose but completely liquefied $5 \%$ gelatin plus $0.1 \%$ maltose after 4 days of incubation.

In addition to the reactions in Table 1, ATCC 29744 produced acid from dextrin and glycogen, as was reported by Blackburn and Hobson (1). There was no growth in the basal broth medium (14) or in the basal medium with adonitol, amygdalin, dulcitol, erythritol, inositol, melezitose, melibiose, pectin, ribose, sorbitol, sorbose, or trehalose; milk was not curdled or digested; lactate, pyruvate, gluconate, and threonine were not utilized; catalase was not formed; cellulose was not digested.

The normal habitat of $B$. amylophilus is the bovine or ovine rumen, where it may be one of the principal starch digesters $(1,17)$.

The guanine-plus-cytosine content of the deoxyribonucleic acid of ATCC 29744 is $42.1 \mathrm{~mol} \%$ (20).

The characteristics of ATCC 29744 agree entirely with those given in the original description of $B$. amylophilus by Hamlin and Hungate (13). This strain is therefore designated the neotype strain of $B$. amylophilus Hamlin and Hungate.

Bacteroides succinogenes Hungate 1950, 13 (later synonym: Ruminobacter succinogenes [Hungate] Prévot 1966, 122 [19]).

The cells of $B$. succinogenes ATCC 19169, after $24 \mathrm{~h}$ in $\mathrm{PY}$-glucose-30\% rumen fluid$\mathrm{Na}_{2} \mathrm{CO}_{3}$ broth, were coccoid to oval in shape, gram negative, 0.8 to $1.6 \mu \mathrm{m}$ wide and 0.9 to 1.6 $\mu \mathrm{m}$ long, and occurred mostly singly or in pairs but occasionally in short chains.

The organism was strictly anaerobic and nonmotile. It did not form spores or survive heating at $80^{\circ} \mathrm{C}$ for $10 \mathrm{~min}$. In earlier studies (5) of the exact nutritional requirements supplied by the rumen fluid and yeast extract, a branched-chain fatty acid (either isovaleric or isobutyric) and a straight-chain fatty acid (either butyric or valeric) as well as biotin, $\mathrm{CO}_{2}, \mathrm{NH}_{3}$, sulfide or cysteine, and some minerals including sodium were found to be essential for growth $(3,6-8)$. The organism did not use amino acid nitrogen. Growth was best at $37^{\circ} \mathrm{C}$ and moderate at $30^{\circ} \mathrm{C}$. There was no growth in $24 \mathrm{~h}$ at 25 or $45^{\circ} \mathrm{C}$.

Colonies in rumen fluid-glucose-cellobioseagar roll tubes (14) after 3 days of incubation were punctiform, circular, entire, convex, transparent, colorless, shiny, and smooth. No internal structure was visible. No individual colonies appeared on freshly prepared blood agar plates incubated anaerobically, although a film appeared on the surface and a few cells were seen in a Gram stain. There was no growth on blood agar plates incubated aerobically or under 5\% $\mathrm{CO}_{2}$ or on egg yolk agar plates incubated anaerobically.

The most significant attribute of these organisms, both taxonomically and economically, is their ability to degrade cellulose. In our first

Table 1. Biochemical characteristics of Bacteroides amylopbilus ${ }^{a}$

\begin{tabular}{lcc}
\hline Reaction & $\begin{array}{c}\text { Hamlin }^{b} \\
\text { and } \\
\text { Hungate (13) }\end{array}$ & $\begin{array}{c}\text { ATCC }^{b} \\
29744\end{array}$ \\
\hline $\begin{array}{l}\text { Hydrolysis of: } \\
\begin{array}{l}\text { Gelatin } \\
\text { Starch }\end{array}\end{array}$ & $\begin{array}{c}\text { variable } \\
+\end{array}$ & + \\
$\begin{array}{l}\text { Fermentable carbohy- } \\
\text { drate required }\end{array}$ & + & + \\
$\begin{array}{l}\text { Products of carbohy- } \\
\text { drate fermentation }\end{array}$ & ASF(L) & SFAl \\
$\begin{array}{l}\text { Final pH in maltose } \\
\text { broth }\end{array}$ & $5.5-5.7$ & 5.5 \\
$\begin{array}{l}\text { Acid from: } \\
\text { Maltose }\end{array}$ & + & + \\
Starch & + & + \\
\hline
\end{tabular}

$a_{\text {Symbols: }- \text {, negative reaction; }+ \text {, positive reaction }}$ (carbohydrate cultures, $\mathrm{pH}$ ( 5.5); A, acetic acid; S, succinic acid; $F$, formic acid; $L$, lactic acid.

$b_{\text {No acid produced from arabinose, cellobiose, }}$ esculin, fructose, galactose, glucose, glycerol, inulin, lactose, mannitol, raffinose, rhamnose, salicin, sucrose, or xylose; indole, hydrogen sulfide and acetylmethylcarbinol not produced; nitrate not reduced; no hydrogen detected from fermentation of maltose.

${ }^{c}$ Products are listed in order of relative amounts detected. Small letter indicates trace amount. ( ), Product sometimes detected. 
attempts to demonstrate cellulolytic ability of ATCC 19169, we used pure cellulose fiber, ground and supplied to us by Celanese Corp., as a substrate in the basal medium. There was no visible growth in this medium and no apparent disappearance of the cellulose over a period of 3 weeks.

We were equally unsuccessful in demonstrating cellulose digestion with either Whatman no. 1 filter paper strips or Whatman chemically prepared cellulose powder.

Forsberg (12) has recently shown that B. succinogenes, in pure culture, is one of the rumen organisms most sensitive to trace elements such as mercury, copper, chromium, selenium, nickel, cadmium, and arsenic. Since any or all of these could be present in the water in our area, or since there might be some volatile inhibitory agent present, we took special care in distilling the water used in making cellulose medium, collected it at $90^{\circ} \mathrm{C}$, and prepared the medium as soon as possible after collection. With $0.2 \%$ (wt/vol) Whatman ashless cellulose powder (standard grade) and $0.01 \%$ cellobiose as a growth booster, the cellulose was visibly and microscopically about $80 \%$ digested in 7 days.

During these studes, it was suggested by P. J. Van Soest that native cellulose such as that in carrots, radishes, or turnips should be tested as a substrate. Accordingly, we added small, thin strips (ca. $2 \mathrm{~mm}$ by $0.5 \mathrm{~cm}$ by $3 \mathrm{~cm}$ ) of each of these raw vegetables to the basal medium before sterilization and repeated the test. Although growth was good and digestion of the substrate was evident in all of the vegetable broths, the results were most dramatic in the broth with the turnip strip. Disintegration of the strip was evident within $24 \mathrm{~h}$, and only small bits were apparent after incubation for 5 days. By 11 days, no gross structures were visible in the broth.

According to Van Soest, turnips have about $10 \%$ dry matter. The approximate composition on a dry matter basis is $20 \%$ cellulose, $20 \%$ pectin (calcium-pectate), 2 to $4 \%$ lipid, 20 to $30 \%$ sugar (principally sucrose), $20 \%$ protein, and ash. The plant cell walls contain the native cellulose and the intracellular layer contains primarily pectin.

To establish that the degradation of the turnip strip was a result of cellulose digestion and not of pectin fermentation, B. vulgatus (VPI B8-11), a pectin fermenter, was used as a control culture. With $B$. vulgatus, the turnip slice broke in two within 5 days and by 11 days was reduced to large flakes. The absence of cellulose digestion was confirmed by microscopic examination of the culture under phase contrast (low-power magnification: $\times 100$ ). Many whole, undigested cell walls were readily apparent, and none showed any evidence of destruction (Fig. 1a). However, in the $B$. succinogenes culture, careful microscopic examination revealed no intact cell walls and only a few partially digested plant cell wall fragments (Fig. 1b).

Determination of cellulolytic activity with turnip slices appears to be a simple and sensitive procedure. Turnip cellulose may more nearly represent the natural substrates of cellulolytic bacteria than highly crystalline or ball-milled cellulose. However, careful attention should be given to possible limitations presented by a possible sparing effect of the other carbohydrates in the structure. Gross disintegration of the plant tissue may be caused by destruction of pectin, and therefore microscopic examination is required to confirm cellulose digestion of the plant cell walls.

We do not know whether the $B$. succinogenes cells digested the turnip pectin or even whether pectin digestion is necessary for destruction of the tissue integrity or for exposing the plant cell wall cellulose for digestion. Although $B$. succinogenes showed no activity on citrus pectin (ICN Pharmaceuticals, Inc., Cleveland, Ohio) as a substrate (Table 2), bacterial pectinolytic activity differs with apple, potato, and presumably other pectins such as turnip pectin.

Cellobiose broth cultures of ATCC 19169 were turbid with a smooth sediment. The final $\mathrm{pH}$ after 4 days of incubation was 5.4. The products of the fermentation of cellobiose were (in milliequivalents per $100 \mathrm{ml}$ ): succinic acid, 6.4; and acetic acid, 1.2.

The reactions of ATCC 19169 after 13 days of incubation in PYRC-based media and the reactions of this species as described by Hungate (16) are listed in Table 3. Although the original isolates were reported to ferment starch, mal-

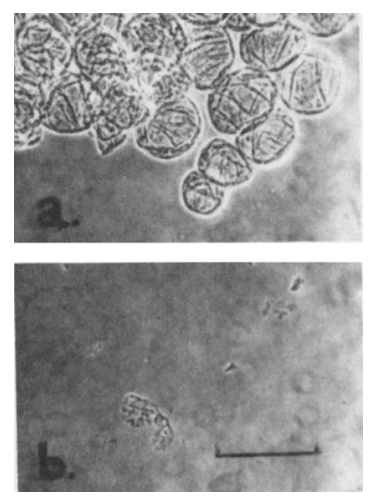

FIg. 1. Turnip cells after 11 days of incubation with: (a) B. vulgatus; (b) B. succinogenes, photographed under phase-contrast microscope (low power: $\times 10$ objective). Bar $=0.3 \mathrm{~mm}$. 
Table 2. Substrate utilization by

$B$. succinogenes and B. vulgatus

\begin{tabular}{lccc}
\hline Medium & $\begin{array}{c}\text { Amount } \\
\text { of } \\
\text { growth }\end{array}$ & $\begin{array}{c}\text { Final } \\
\text { pH }\end{array}$ & $\begin{array}{c}\text { Digestion } \\
\text { of turnip } \\
\text { cell walls }\end{array}$ \\
\hline $\begin{array}{l}\text { Uninoculated } \\
\text { PYRC } b\end{array}$ & - & 6.4 & \\
$\begin{array}{l}\text { PYRC-turnip } \\
\text { PYRC-citrus }\end{array}$ & - & 6.2 & - \\
pectin & - & 5.8 & \\
$\begin{array}{l}\text { ATCC 19169 } \\
\text { PYRC }\end{array}$ & & & \\
$\begin{array}{l}\text { PYRC-turnip } \\
\text { PYRC-citrus }\end{array}$ & +++ & 6.1 & \\
pectin & + & $5.6^{c}$ & ++++ \\
$\begin{array}{l}\text { B. vulgatus } \\
\text { PYR }\end{array}$ & & & \\
PYR-turnip & +++ & 6.2 & \\
PYR-citrus & ++++ & 5.1 & - \\
pectin & ++++ & 5.2 & \\
\hline
\end{tabular}

${ }^{a}$ Growth estimated on $\mathrm{a}+$ to ++++ basis.

$b_{\text {PYRC }}=\mathrm{PY}-30 \%$ rumen fluid $-\mathrm{Na}_{2} \mathrm{CO}_{3}$.

$c_{\text {Products of the fermentation of turnip were (in }}$ $\mathrm{meq} / 100 \mathrm{ml}$ ) : succinic acid, 8.14; acetic acid, 0.97; a trace of formic acid.

Table 3. Biochemical characteristics of Bacteroides succinogenes ${ }^{a}$

\begin{tabular}{lcc}
\hline Reaction & Hungate $^{b}$ & ATCC $^{b}$ \\
& (16) & 19169 \\
\hline
\end{tabular}

Acid from:

Cellobiose

Cellulose

Dextrin

Glucose

Lactose

Maltose

Starch

Trehalose

Products of cellulose fermentation: Acids SAf $c$ SAf

${ }^{a}$ Symbols: - , negative reaction; + , positive reaction (culture $\mathrm{pH}$ below 5.5); $\mathrm{w}, \mathrm{pH}$ between 5.5 and 6.0; S, succinic acid; A, acetic acid; F, formic acid.

$b_{\text {No acid was produced from arabinose, dulcitol, }}$ fructose, galactose, glycerol, inositol, inulin, mannitol, mannose, melezitose, melibiose, pectin, raffinose, rhamnose, salicin, sorbitol, sucrose, or $\mathrm{xy}$ lose; no hydrogen or carbon dioxide was detected from cellulose fermentation.

${ }^{c}$ Products are listed in order of relative amounts. Small letters indicate trace amounts. tose, trehalose, and dextrin, Hungate later stated (17) that fermentation of these, as well as of lactose or pectin, may be variable. We found, as was previously reported by Bryant and Doetsch (5), that ATCC 19169 did not ferment xylan, gum arabic, or esculin, did not produce indole or acetylmethylcarbinol, and did not reduce nitrate or hydrolyze gelatin.

In addition to these reactions, ATCC 19169 did not ferment adonitol, amygdalin, erythritol, glycogen, ribose, or sorbose. There was no change in milk and no growth in lactate, pyruvate, threonine, or gluconate broth. $\mathrm{H}_{2} \mathrm{~S}$ was not formed in SIM medium (BBL Microbiology Systems).

The normal habitat of $B$. succinogenes is the rumen.

The guanine-plus-cytosine content of the deoxyribonucleic acid of ATCC 19169 is $42.8 \mathrm{~mol} \%$ (20).

Since the characteristics of ATCC 19169 agree essentially with Hungate's original and later descriptions of $B$. succinogenes (15-17), this strain is here designated the neotype strain of Bacteroides succinogenes Hungate.

\section{ACKNOWLEDGMENTS}

We gratefully acknowledge the excellent technical assistance and enthusiastic support of Luba Fabrycky and the helpful suggestions of P. J. Van Soest.

This work was supported by Public Health Service grant GM-14604 from the National Institute of General Medical Science (Virginia Polytechnic Institute), U.S. Department of Agriculture grant 35-331, and the Agriculture Experiment Station (University of Illinois).

\section{REPRINT REQUESTS}

Address reprint requests to: Elizabeth P. Cato, Anaerobe Laboratory, College of Agriculture and Life Sciences, Virginia Polytechnic Institute and State University, Blacksburg, VA 24061.

\section{LTTERATURE CITED}

1. Blackburn, T. H., and P. N. Hobson. 1962. Further studies on the isolation of proteolytic bacteria from the sheep rumen. J. Gen. Microbiol. 29:69-81.

2. Bryant, M. P. 1959. Bacterial species of the rumen. Bacteriol. Rev. 23:125-153.

3. Bryant, M. P. 1973. Nutritional requirements of the predominant rumen cellulolytic bacteria. Fed. Proc. 32:1809-1813.

4. Bryant, M. P., and L. A. Burkey. 1953. Cultural methods and some characteristics of some of the more numerous groups of bacteria in the bovine rumen. J. Dairy Sci. 36:205-217.

5. Bryant, M. P., and R. N. Doetsch. 1954. A study of actively cellulolytic rod-shaped bacteria of the bovine rumen. J. Dairy Sci. 37:1176-1183.

6. Bryant, M. P., and R. N. Doetsch. 1955. Factors necessary for the growth of Bacteroides succinogenes in the volatile acid fraction of rumen fluid. J. Dairy Sci. 38:340-350.

7. Bryant, M. P., and I. M. Robinson. 1962. Some nutritinal characteristics of predominant culturable ruminal bacteria. J. Bacteriol. 84:605-614.

8. Bryant, M. P., and I. M. Robinson. 1963. Apparent incorporation of ammonia and amino acid carbon dur- 
ing growth of selected species of ruminal bacteria. J. Dairy Sci. 46:150-154.

9. Bryant, M. P., I. M. Robinson, and H. Chu. 1959. Observations on the nutrition of Bacteroides succinogenes-a ruminal cellulolytic bacterium. J. Dairy Sci. 42:1831-1847.

10. Caldwell, D. R., M. Keeney, and P. J. Van Soest. 1969. Effects of carbon dioxide on growth and maltose fermentation by Bacteroides amylophilus. J. Bacteriol. 98:668-676.

11. Dehority, B. A. 1963. Isolation and characterization of several cellulolytic bacteria from in vitro rumen fermentations. J. Dairy Sci. 46:217-222.

12. Forsberg, C. W. 1978. Effects of heavy metals and other trace elements on the fermentative activity of the rumen microflora and growth of functionally important rumen bacteria. Can. J. Microbiol. 24:298-306.

13. Hamlin, L. J., and R. E. Hungate. 1956. Culture and physiology of a starch-digesting bacterium (Bacteroides amylophilus n. sp.) from the bovine rumen. J. Bacteriol. 72:548-554.

14. Holdeman, L. V., E. P. Cato, and W. E. C. Moore (ed.).
1977. Anaerobe laboratory manual, 4th ed. Virginia Polytechnic Institute and State University, Blacksburg.

15. Hungate, R. E. 1947. Studies on cellulose fermentation. III. The culture and isolation of cellulose-decomposing bacteria from the rumen of cattle. J. Bacteriol. 53:631-645.

16. Hungate, R. E. 1950 . The anaerobic mesophilic cellulolytic bacteria. Bacteriol. Rev. 14:1-49.

17. Hungate, R. E. 1966. The rumen and its microbes, p. 65. Academic Press Inc., New York.

18. Lapage, S. P., P. H. A. Sneath, E. F. Lessel, V. B. D. Skerman, H. P. R. Seeliger, and W. A. Clark (ed.). 1975. International code of nomenclature of bacteria, $p$. 19. American Society for Microbiology, Washington, D.C.

19. Prévot, A.-R. 1966. Manual for the classification and determination of the anaerobic bacteria, p. 121-122. First American ed., translated by V. Fredette. Lea and Febiger, Philadelphia.

20. Reddy, C. A., and M. P. Bryant. 1977. Deoxyribonucleic acid base composition of certain species of the genus Bacteroides. Can. J. Microbiol. 23:1252-1256. 